\title{
Differing utilization of glucose and algal particulate organic matter by deep-sea benthic organisms of Sagami Bay, Japan
}

\author{
Hidetaka Nomaki*, Nanako O. Ogawa, Yoshinori Takano, Hisami Suga, \\ Naohiko Ohkouchi, Hiroshi Kitazato
}

Institute of Biogeosciences, Japan Agency for Marine-Earth Science and Technology (JAMSTEC), 2-15 Natsushima-cho, Yokosuka 237-0061, Japan

\begin{abstract}
The fate of particulate and dissolved organic carbon in deep-sea benthic organisms was evaluated by in situ ${ }^{13} \mathrm{C}$-labeling experiments in the central part of Sagami Bay, Japan (water depth: $1453 \mathrm{~m}) .{ }^{13} \mathrm{C}$-labeled glucose and Chlorella sp. (Chlorophyta) were injected into a series of in situ culture cores and incubated for 0 to $9 \mathrm{~d}$. Glucose was chosen as an example of labile dissolved organic matter in the pore water, and Chlorella sp. as an example of fresh algal material. Incorporation of both carbon sources by benthic foraminifera and metazoans was determined based on enrichment in ${ }^{13} \mathrm{C}$ of their bulk tissues. Archaeal incorporations were also evaluated by examining ${ }^{13} \mathrm{C}$-labeled lipid biomarkers. Chlorella sp. incorporation by foraminiferal species ranged from 0.0 to $40 \%$ of their biomass. Foraminiferal ingestion of algal materials varied markedly among the same species depending on body size or individual differences. All species incorporated glucose to similar extents, ranging from 0.1 to $0.3 \%$ of their biomass. Many foraminiferal species incorporated glucose faster than Chlorella sp. After $9 \mathrm{~d}$ of in situ incubation, 26.4, 1.7, 0.1, and 3.8\% of added Chlorella sp. was detected in the bulk sediment, foraminiferal biomass, examined metazoan biomass, and respired $\mathrm{CO}_{2}$, respectively. The figures for glucose were 5.3, $0.04,0.00$, and $4.6 \%$, respectively. Labile dissolved organic matter may serve as an accessible food source for benthic organisms and is quickly mineralized on the deep seafloor.
\end{abstract}

KEY WORDS: Benthic foraminifera $\cdot$ Dissolved organic matter $\cdot$ Particulate organic matter $\cdot$ Benthic ecosystem · Carbon budget · In situ tracer experiment

\section{INTRODUCTION}

Phytodetritus and its degraded components are thought to be major food sources in deep-sea benthic ecosystems because of their lability (Graf 1987, Pfannkuche 1993), which triggers a rapid response by the benthic community. Rapid responses to phytodetritus input by a number of deep-sea benthic taxonomic groups, including bacteria (Lochte \& Turley 1988, Pfannkuche et al. 1999), protozoa (Gooday 1988, Gooday \& Turley 1990, Drazen et al. 1998, Kitazato et al. 2000), and megafauna (Tyler \& Gage 1984, Campos-
Creasey et al. 1994, Witte 1996), have been recorded. Among the benthic organisms, foraminifera are known to play important roles in phytodetritus consumption by ingesting substantial amounts of algae or degraded algal materials (Moodley et al. 2002, Nomaki et al. 2005, 2006, Gooday et al. 2008) and by degrading them (Nomaki et al. 2009), in particular in dysoxic environments (Woulds et al. 2007). Benthic foraminifera also serve as a nutritional source for higher trophic levels, such as some metazoan meio- and macrofauna (Hickman \& Lipps 1983, Gudmundsson et al. 2000, Nomaki et al. 2008, Shimanaga et al. 2009). Knowledge of ben- 
thic foraminiferal feeding habits are therefore crucial to understand benthic food webs and resultant biogeochemical cycles on the seafloor.

Among the complex food webs on the seafloor, dissolved organic carbon (DOC) produced in situ is assumed to play important roles in addition to phytodetritus. For some benthic organisms, DOC may be an accessible form of nourishment, since the DOC concentration is abundant in pore water relative to overlying water (Burdige 2002). Two agglutinated foraminiferal species from Antarctic shallow water utilize dissolved amino acids directly (DeLaca et al. 1981, DeLaca 1982). The latter 2 studies suggested that foraminifera adapt to highly seasonal oligotrophic environments by utilizing DOC. Dissolved organic matter (DOM) is the largest pool of organic matter in the ocean (Libes 2009). The concentration of DOC in sedimentary pore water is generally higher than that in the overlying seawater by values up to an order of magnitude, although most DOC is presumably refractory (Burdige 2002). This implies that some of the labile molecular components of the DOC could be possible carbon sources for deep-sea foraminiferal species.

The uptake of DOC by a number of benthic taxonomic groups, including bacteria (Cahet et al. 1990, Guilini et al. 2010), benthic foraminifera (DeLaca et al. 1981, DeLaca 1982), marine invertebrates (Shirayama 1992, Baines et al. 2005, de Goeij et al. 2008, Guilini et al. 2010), and whole benthic communities (Sawyer \& King 1993, van Oevelen et al. 2006a,b) has been reported. However, most previous studies were limited to shallow-water organisms that can utilize relatively large amounts of organic matter produced on the ocean surface. Since the deep seafloor is generally oligotrophic in comparison with shallow-water areas, responses to labile DOC by deep-sea benthic organisms should differ from those in shallow water.

It is also obvious that archaea, in addition to bacteria, are important components of deep-sea benthic communities, particularly in subsurface sediments (Lipp et al. 2008). However, their activities on the deep-sea floor are still unclear due to difficulties in culturing them in the laboratory.

In the present study, we investigated whether DOC is a suitable carbon source for deep-sea benthic foraminifera and other organisms, including archaea in the bathyal Sagami Bay. The fate of glucose carbon as an example of labile DOC was followed in ${ }^{13} \mathrm{C}$-tracer experiments. The ${ }^{13} \mathrm{C}$-tracer experiments were carried out in situ, since the metabolism of deep-sea microorganisms is reduced at a pressure of $1 \mathrm{~atm}$ (Cahet et al. 1990). ${ }^{13} \mathrm{C}$-labeled glucose was added to the overlying seawater at the deep seafloor, and subsequent incorporation and mineralization of the label was examined in heterotrophs in the sediments, ranging from archaea to benthic foraminifera to some metazoans. ${ }^{13} \mathrm{C}$-labeled Chlorella sp., as an example of fresh algal materials, was tested in the same way, and the utilization processes of glucose and Chlorella sp. were compared. The present study focused on benthic foraminifera, because they are known to consume substantial amounts of organic carbon on the deep-sea floor (Moodley et al. 2002, Gooday et al. 2008). Total uptake rates of ${ }^{13} \mathrm{C}$-labeled substrates by archaea were not quantified since (1) the archaeal biomass estimation based on the concentration of lipid biomarkers has some variables and (2) the rates of incorporation of ${ }^{13} \mathrm{C}$ to archaeal membrane lipids were highly heterogeneous between glycerol and isoprenoid (Takano et al. 2010), making it difficult to estimate total archaeal uptake rate using a single membrane lipid biomarker.

\section{MATERIALS AND METHODS}

In situ feeding experiments. In situ feeding experiments were carried out in March 2006 during cruises NT06-04 and NT06-05 of the RV 'Natsushima'. Details of the oceanic settings and benthic processes were reported in a series of papers on Project Sagami (Kanda et al. 2003, Kitazato et al. 2003, Nakatsuka et al. 2003) and on in situ experiments (Nomaki et al. 2005, 2006, 2009).

In situ culture cores with a surface sediment area of $52.8 \mathrm{~cm}^{2}$ (diameter: $8.2 \mathrm{~cm}$, core length: $32 \mathrm{~cm}$ ) were used in the present study. Details of the in situ culture core were described by Nomaki et al. (2009) and Takano et al. (2010). Approximately $600 \mathrm{ml}$ of overlying water was present in the top of the culture cores. Two holes (diameter: $1.5 \mathrm{~cm}$ ) were left open at the top of the core to facilitate water outflow during core insertion. Every core had two $5 \mathrm{ml}$ syringes that contained ${ }^{13} \mathrm{C}$-labeled algae, Chlorella sp. (2.00 mg C core $^{-1}$, $>98{ }^{13} \mathrm{C}$ atom\%; Cambridge Isotope) that had been lyophilized and powdered, or uniformly ${ }^{13} \mathrm{C}$-labeled glucose $\left(6.80 \mathrm{mg} \mathrm{C}\right.$ core $^{-1}, 98.7{ }^{13} \mathrm{C}$ atom $\%$; Cambridge Isotope). The injection part of the syringe was generally located $8 \mathrm{~cm}$ above the sediment-water interface (Fig. 1). ${ }^{13} \mathrm{C}$-labeled Chlorella sp. added to the surface sediments corresponded to $379 \mathrm{mg} \mathrm{C} \mathrm{m}^{-2}$. The carbon concentration of Chlorella sp. corresponded to the daily flux of total organic carbon (TOC) in the central part of Sagami Bay ( 200 to $500 \mathrm{mg} \mathrm{C} \mathrm{m}^{-2} \mathrm{~d}^{-1}$; Kitazato et al. 2003, Nakatsuka et al. 2003). The initial carbon concentration of added ${ }^{13} \mathrm{C}$-labeled glucose in the overlying water $(600 \mathrm{ml})$ of the culture core was calculated to be $944 \mu \mathrm{M}$, which is higher than that in the overlying water at this site, but within the range of the DOC concentration in the sediment pore water $(\sim 500$ to $2000 \mu \mathrm{M})$. Since the culture core was not a closed 
system, the concentration of ${ }^{13} \mathrm{C}$-labeled glucose may have decreased during the incubation periods, not only by degradation, but also by diffusion.

In situ culture cores were deployed on the undisturbed seafloor (water depth: $1453 \mathrm{~m}$ ) by the ROV 'Hyper-Dolphin' (remotely operated vehicle; Fig. 1). Culture cores were maintained some 10s of centimeters away from each other. After positioning the culture cores, ${ }^{13} \mathrm{C}$-labeled food materials were introduced to the surface sediments. Two Chlorella sp. cores were incubated in situ for 2 and 9 d (C-2 and C-9, respectively). Three glucose cores were incubated in situ for 0, 1, and 9 d (G-0, G-1, and G-9, respectively). Because of limitations in the ROV payload and working time on the seafloor, only a single core was sampled for each substrate and at each time point. The data presented in the present paper need to be interpreted with caution, since it is known that the response of organisms to an artificial food supply varies greatly, especially among macrofauna (e.g. Aberle \& Witte 2003). The G-0 core was not examined for the faunal study, but was analyzed for archaeal lipids, bulk sediment, and overlying water.

Additionally, each of the Chlorella sp. and glucose cores was incubated in situ for 405 d (Takano et al. 2010). Dissolved oxygen concentration in the overlying water of the glucose core incubated for $405 \mathrm{~d}$ was $10.4 \%$ saturation, which is less than that of ambient seawater (17.7\% saturation). This implies that the top part of the core became dysoxic due to less circulation of seawater, but not totally anoxic even after $405 \mathrm{~d}$ of in situ incubation. The isotopic data on sediment and organisms from cores incubated for $405 \mathrm{~d}$ are not reported in the current paper.

Sample processing. Onboard, all recovered culture cores were kept at $4^{\circ} \mathrm{C}$ prior to core processing (typically within $1 \mathrm{~h}$ ). Three $20 \mathrm{ml}$ bottles of overlying water samples were gently collected from all cores to determine ${ }^{13} \mathrm{C}$ concentrations of dissolved inorganic carbon (DIC). Soon after collection, the samples were poisoned with $\mathrm{HgCl}_{2}$, sealed with a rubber septumaluminum cap, and then stored at $4{ }^{\circ} \mathrm{C}$ prior to further analyses. Sediments were sliced at $1 \mathrm{~cm}$ intervals from 0 to $5 \mathrm{~cm}$ in depth, followed by the collection of 5 to 7,7 to 10 , and 10 to $15 \mathrm{~cm}$ sediment depth samples (Table S1 in the supplement at www.int-res. com/articles/suppl/m431p011_supp.pdf). Subsamples $\left(15 \mathrm{~cm}^{3}\right)$ of the sediments were used for the analysis of bulk organic matter and archaeal membrane lipid analysis (Takano et al. 2010). These samples were kept frozen at $-80^{\circ} \mathrm{C}$ and then freeze-dried. The remaining sediments at 0 to $5 \mathrm{~cm}$ in depth were used for the determination of carbon isotopic compositions of the benthic organisms. They were sieved on a $125 \mu \mathrm{m}$ mesh with organic carbon $\left(\mathrm{C}_{\text {org }}\right)$-free artificial seawater and then
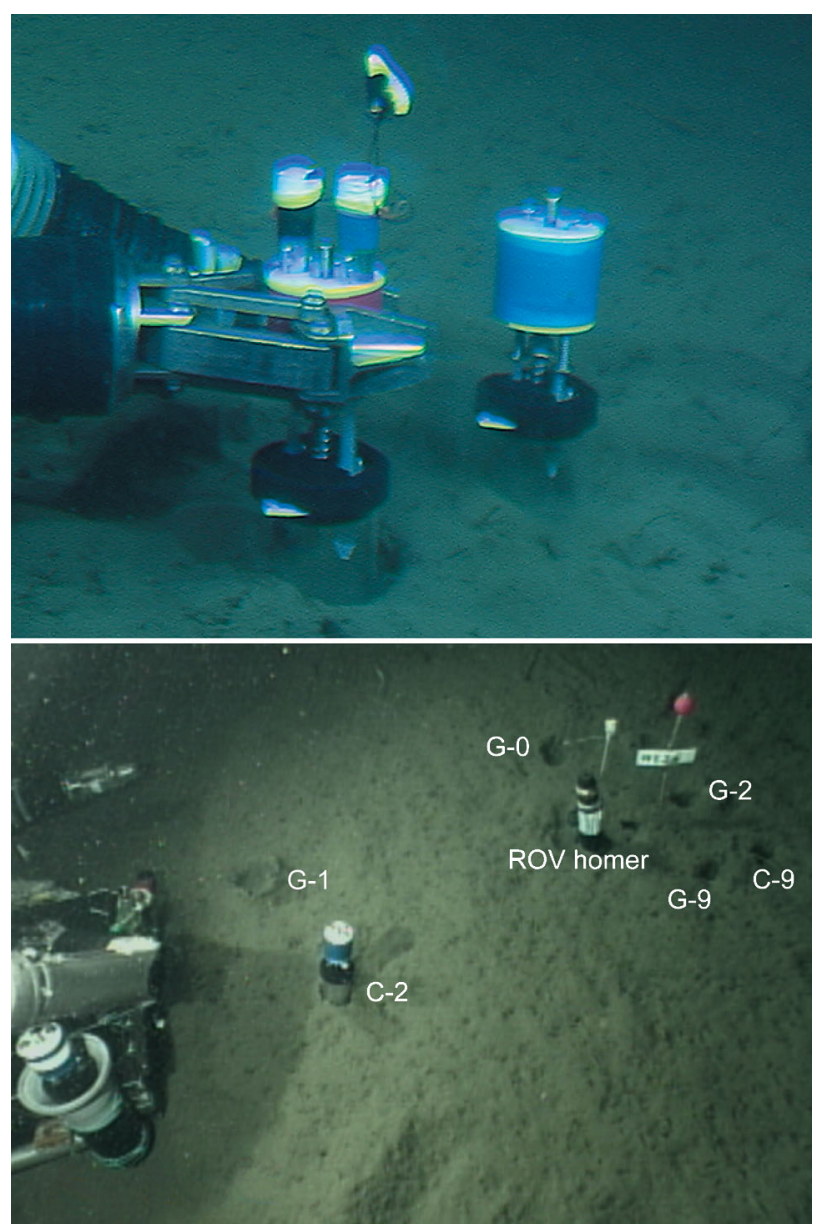

Fig. 1. In situ culture cores deployed on the seafloor. Upper panel: deployment of C-9 core (right) and G-9 core (left). Triggers have already been taken off the C-9 core. Lower panel: deployment of in situ culture cores and a remotely operated vehicle (ROV) homer. ROV 'Hyper-Dolphin' can be seen on the left

stored at $-40^{\circ} \mathrm{C}$ prior to the isolation of benthic organisms from the sediments.

In the laboratory, metazoans and benthic foraminifera, of which the test cavity was filled with cytoplasm, were picked from the sediments under a binocular stereoscopic microscope. Specimens of Cyclammina cancellata Brady, Uvigerina akitaensis Asano, Bolivina spissa Cushman, Globobulimina affinis d'Orbigny, and Chilostomella ovoidea Reuss were selected for isotopic analyses (Tables S2 \& S3 in the supplement at www. int-res.com/articles/suppl/m431p011_supp.pdf). Typically, from 5 to 25 specimens were prepared for each measurement of isotopic composition except for the analyses of $C$. cancellata, for which from 1 to 3 specimens sample ${ }^{-1}$ were prepared. Samples were prepared as replicates if specimen numbers were sufficient. We divided the $U$. akitaensis from the 0 to $2 \mathrm{~cm}$ 
layer of C-9 into 4 samples: 2 samples consisted of normal, brown cytoplasmic specimens and the other 2 samples consisted of green specimens, which indicated ingestion of the Chlorella sp. added to the incubation core (Hemleben \& Kitazato 1995). Bathysiphon and mudball (presumably Komokiacea) were also picked and prepared for isotopic analyses.

Some metazoan meiofauna (copepods, meiofaunal size bivalves, and meiofaunal size polychaetes) and macrofauna (cumaceans) were also picked from the sediments. Since sediment samples were examined after freezing and thawing, some fragile taxa such as nematodes were less abundant relative to the in situ population (Shimanaga \& Shirayama 2000) and were not measured in the present study. A lack of dye would also contribute insufficient collection of metazoan samples from the sediments.

The powdered sediments were weighed and transferred into silver cups that had been prewashed with $\mathrm{MeOH}$ and dichloromethane $(1: 1, \mathrm{v} / \mathrm{v}$; Ogawa et al. 2010). Both foraminifera and metazoans were cleaned with artificial seawater to remove adherent particles. They were transferred into the silver cups and dried at $50^{\circ} \mathrm{C}$. All samples were decalcified with $2 \mathrm{~N} \mathrm{HCl}$, followed by drying on a hotplate. Dried silver cups containing decalcified samples were sealed into precleaned tin cups prior to isotopic analysis. Although the aqueous acidification procedure sometimes gives altered values of carbon isotopic compositions (up to $0.5 \%$; Komada et al. 2008), the effect is minor here, since the degrees of ${ }^{13} \mathrm{C}$-enrichment were enough high.

Archaeal lipid quantification. Archaea is 1 of the 3 domains of life on Earth and is subdivided based on 16S rRNA in 2 major phyla (Euryarchaeota and Crenarchaeota). Diether lipids (e.g. archaeol) and tetra-ether lipids (e.g. GDGTs; glycerol dialkyl glycerol tetraethers) in the membrane tissue are archaeaspecific biomarkers having isoprenoid moieties (Sinninghe Damsté et al. 2002, Boucher et al. 2004, Koga \& Morii 2007, Koga \& Nakano 2008). Among these, GDGTs in the marine environment often contain cyclohexane and cyclopentane rings formed by internal cyclisation of the biphytanyl chains, namely GDGT(0), GDGT(1), GDGT(2), GDGT(3), and GDGT(5); GDGT(0) and GDGT(5) are also called caldarchaeol and crenarchaeol, respectively (see Fig. S1 in the supplement at www.int-res.com/ articles/suppl/m431p011_supp.pdf) (DeLong et al. 1998, Lipp et al. 2008). By measuring the carbon isotopic compositions of these membrane lipid biomarkers, we evaluated archaeal incorporations of ${ }^{13} \mathrm{C}$-labeled glucose and Chlorella sp. during the experiments.

The method of Takano et al. (2010) for the determination of archaeal lipids, including diether archaeol and putative GDGT, was applied without the copper acetate procedure for the pre-treatment of chlorophyll derivatives. Briefly, after the addition of the internal

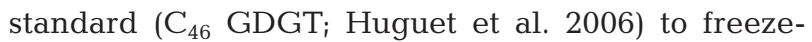
dried sediments (ca. 0.2 g), we extracted archaeal lipids, including archaeol and GDGT, by ultrasonication (20 $\mathrm{min})$ and centrifuged $(777 \times g, 5 \mathrm{~min})$ the extracts 3 times with methanol, 3 times with dichloromethane (DCM):methanol $(1: 1, \mathrm{v} / \mathrm{v})$, and 3 times with DCM during solid-liquid extraction. All extracts were combined and then dried under a nitrogen flow. Five milliliters of distilled water and $5 \mathrm{ml}$ of $n$-hexane:n-propanol $(99: 1, \mathrm{v} / \mathrm{v})$ were added, and samples were shaken for $1 \mathrm{~min}$ for liquid-liquid extraction, a process performed 3 times. The recovered $n$-hexane:n-propanol (99:1, v/v) was then dried under a nitrogen flow and redissolved in $1000 \mu \mathrm{l}$ of $n$ hexane:n-propanol $(99: 1, \mathrm{v} / \mathrm{v})$.

Using high-performance liquid chromatography combined with atmospheric-pressure chemical ionization mass spectrometry (HPLC/APCI-MS, Agilent 1100), the recovered tetraether core lipids were eluted isocratically with $99 \% n$-hexane and $1 \% n$ propanol for $5 \mathrm{~min}$, followed by a linear gradient to $1.8 \% n$-propanol with a flow rate of $0.2 \mathrm{ml} \mathrm{min}^{-1}$. After each analysis, the column was cleaned by backflushing with $n$-hexane: $n$-propanol $(90: 10, \mathrm{v} / \mathrm{v})$ at a flow rate of $0.2 \mathrm{ml} \mathrm{min}^{-1}$ for $10 \mathrm{~min}$ and reconditioned using $n$-hexane: $n$-propanol $(99: 1, \mathrm{v} / \mathrm{v})$ at a flow rate of $0.2 \mathrm{ml} \mathrm{min}{ }^{-1}$ for $10 \mathrm{~min}$. Separation was achieved on a Prevail Cyano column $(2.1 \times 150 \mathrm{~mm}, 3 \mu \mathrm{m}$; Alltech) fitted with the same packing guard column $(4 \times$ $7.5 \mathrm{~mm}$; Alltech). The guard column and main column were maintained at $40^{\circ} \mathrm{C}$ in a column oven with a preheating system (Polaratherm). Positive-ion spectra were generated by total-ion chromatogram (TIC) scanning of $\mathrm{m} / \mathrm{z}$ (specific mass to charge ratio) 500 to 2000. Although we detected extractable archaeol using cultured Methanobacterium sp. (Takano et al. 2009), the amount of archaeol was below the detection limit in the present sediment samples from Sagami Bay.

Determination of organic and inorganic carbon isotope ratios. Carbon isotopic compositions of sediments and benthic organisms along with TOC contents were determined with an isotope ratio monitoring mass spectrometer (Delta plus XP, ThermoFinnigan) connected to an elemental analyzer (FlashEA1112, CE instruments). The isotope ratios were expressed by $\delta$-notation as $\delta^{13} \mathrm{C}(\%)=$ $\left[\left({ }^{13} \mathrm{C} /{ }^{12} \mathrm{C}\right)_{\text {sample }} /\left({ }^{13} \mathrm{C} /{ }^{12} \mathrm{C}\right)_{\text {standard }}-1\right] \times 1000$. The inhouse standard of tyrosine $\left(\delta^{13} \mathrm{C}:-20.5 \%\right)$ was used as a working standard. We also determined the carbon isotopic composition of the purified lipid compounds without pretreatment with internal standard quantification using an isotope ratio mass spectro- 
meter (Delta plus XP, ThermoFinnigan) coupled with a Flash elemental analyzer (EA1112, ThermoFinnigan) via a Conflo III interface.

${ }^{13} \mathrm{C}$ concentrations of DIC in the overlying water were measured by extracting the $\mathrm{CO}_{2}$ gas from the seawater samples. In the laboratory, $3 \mathrm{ml}$ of the bottled overlying seawater was mixed with $0.5 \mathrm{ml}$ of pure $\mathrm{H}_{3} \mathrm{PO}_{4}$ in a vacuum chamber to extract dissolved $\mathrm{CO}_{2}$ gas in the seawater. The liberated $\mathrm{CO}_{2}$ with a small amount of $\mathrm{H}_{2} \mathrm{O}$ was purified through repeated freezing and thawing. The carbon isotopic ratio of the purified $\mathrm{CO}_{2}$ was measured using a stable isotope mass spectrometer (IsoPrime, GV Instruments). Standard $\mathrm{CO}_{2}$ gas $\left(\delta^{13} \mathrm{C}:-3.64 \%\right)$ was used as a working standard. The overall precision of $\delta^{13} \mathrm{C}$ analyses was $\sim 0.1 \%$ o based on analyses of different aliquots of a seawater sample. When the ${ }^{13} \mathrm{C}$ concentration in a sample was high (i.e. greater than $\sim 100 \%$ ), the seawater sample was proportionally $(\sim 1: 10$ to $1: 100)$ mixed with surface seawater that had a known isotopic value (see Table S4 in the supplement at www.int-res.com/articles/suppl/ m431p011_supp.pdf). The carbon isotopic composition of the original seawater sample was calculated from the isotope mass balance equation of the measured sample and added surface seawater samples. Those dilution samples were prepared as duplicate or triplicate samples independently to ensure the accuracy of the measurements. Samples diluted at different volume ratios with surface seawater showed similar values (e.g. $\delta^{13} \mathrm{C}$ of overlying water DIC from G-9 had values of 4184 and $4273 \%$ for a sample to surface seawater ratio of 0.00948 , and $4185 \%$ or a ratio of 0.06613), suggesting that the dilution process did not markedly affect the original value. The error between duplicate measurements with high concentrations of ${ }^{13} \mathrm{C}$ showed seemingly high deviation (up to $89 \%$ in the case of the G-9 core), but overall error for the estimated mineralization rate was only $2.1 \%$, since the labeling was sufficiently great.

Enrichment in ${ }^{13} \mathrm{C}$ was expressed as $\Delta \delta^{13} \mathrm{C}$, indicating a relative increase in $\delta^{13} \mathrm{C}$ in the sample compared with the background value of natural samples, and was calculated as:

$$
\Delta \delta^{13} \mathrm{C}(\%)=\delta^{13} \mathrm{C}_{\text {sample }}-\delta^{13} \mathrm{C}_{\text {background }}
$$

$\delta^{13} \mathrm{C}_{\text {background }}$ values for benthic foraminifera were reported by Nomaki et al. (2008).

Carbon isotopic compositions of foraminiferal samples in the Chlorella sp. experiments were also expressed as excess ${ }^{13} \mathrm{C}$ atom\% of foraminiferal biomass since some species showed high concentrations of ${ }^{13} \mathrm{C}$ in the samples.

To quantify the inventory of ${ }^{13} \mathrm{C}$-labeled materials, we calculated the fraction of carbon originating from added food materials in the TOC of the measured sample, $f_{\text {sample }}$ (Middelburg et al. 2000, Nomaki et al. 2005,2006 ). The amount of incorporated food materials by each benthic organism can be formulated as follows:

$$
M=B_{\text {sample }} \times f_{\text {sample }}
$$

where $M$ and $B$ are the amounts of incorporated food material $\left(\mathrm{g} \mathrm{C} \mathrm{m}^{-2}\right)$ and biomass of the organism ( $\mathrm{g} \mathrm{C}$ $\mathrm{m}^{2}$ ), respectively. Archaeal uptake was not quantified, since the archaeal biomass estimation based on the concentration of lipid biomarkers has some variables, and the incorporation of ${ }^{13} \mathrm{C}$ into the membrane lipid biomarker does not represent the total uptake of archaea.

\section{RESULTS}

\section{Mixing of ${ }^{13} \mathrm{C}$-labeled carbon into sediments}

Temporal deliveries of ${ }^{13} \mathrm{C}$-labeled materials deeper into the sediments were indicated by enriched carbon isotopic compositions of TOC of the bulk sediments (Fig. 2, Table $\mathrm{S} 1$ in the supplement). Both ${ }^{13} \mathrm{C}$-labeled Chlorella sp. and glucose were mixed into the sediment to a similar degree.

Peak concentrations of ${ }^{13} \mathrm{C}$-labeled organic matter were observed in the uppermost $1 \mathrm{~cm}$ of the sediments in every time series for the 2 carbon sources. Penetration depths of ${ }^{13} \mathrm{C}$-labeled organic matter did not differ

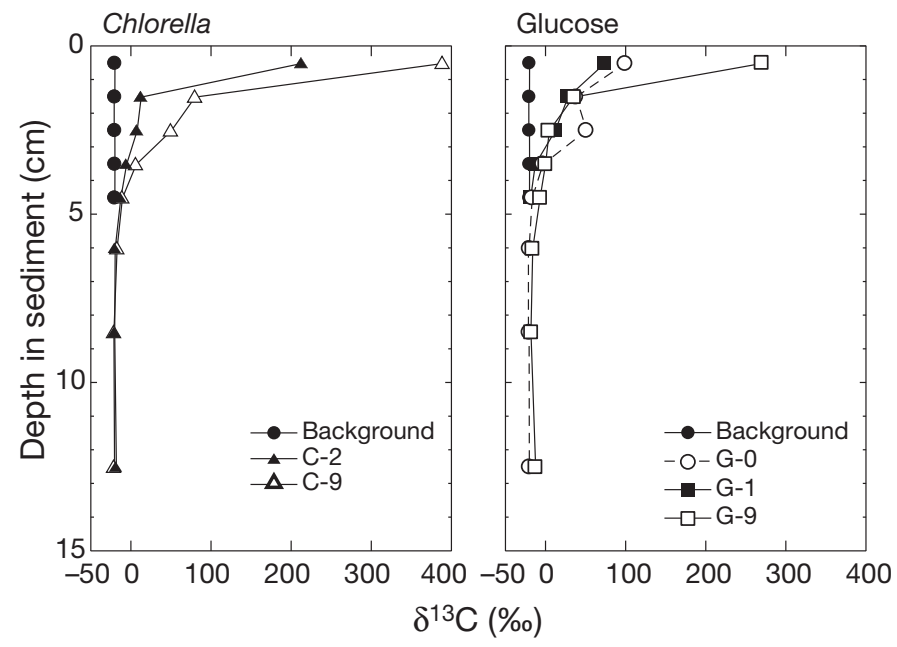

Fig. 2. Vertical profiles of carbon isotopic compositions in experimental cores and a natural background core. Left: profiles of cores to which Chlorella sp. was added for 2 or $9 \mathrm{~d}$ (C-2 and C-9, respectively); right: profiles of cores to which glucose was added for 0, 1, or 9 d (G-0, G-1, and G-9, respectively). See Table $\mathrm{S} 1$ in the supplement at www.intres.com/articles/suppl/m431p011_supp.pdf for raw data 


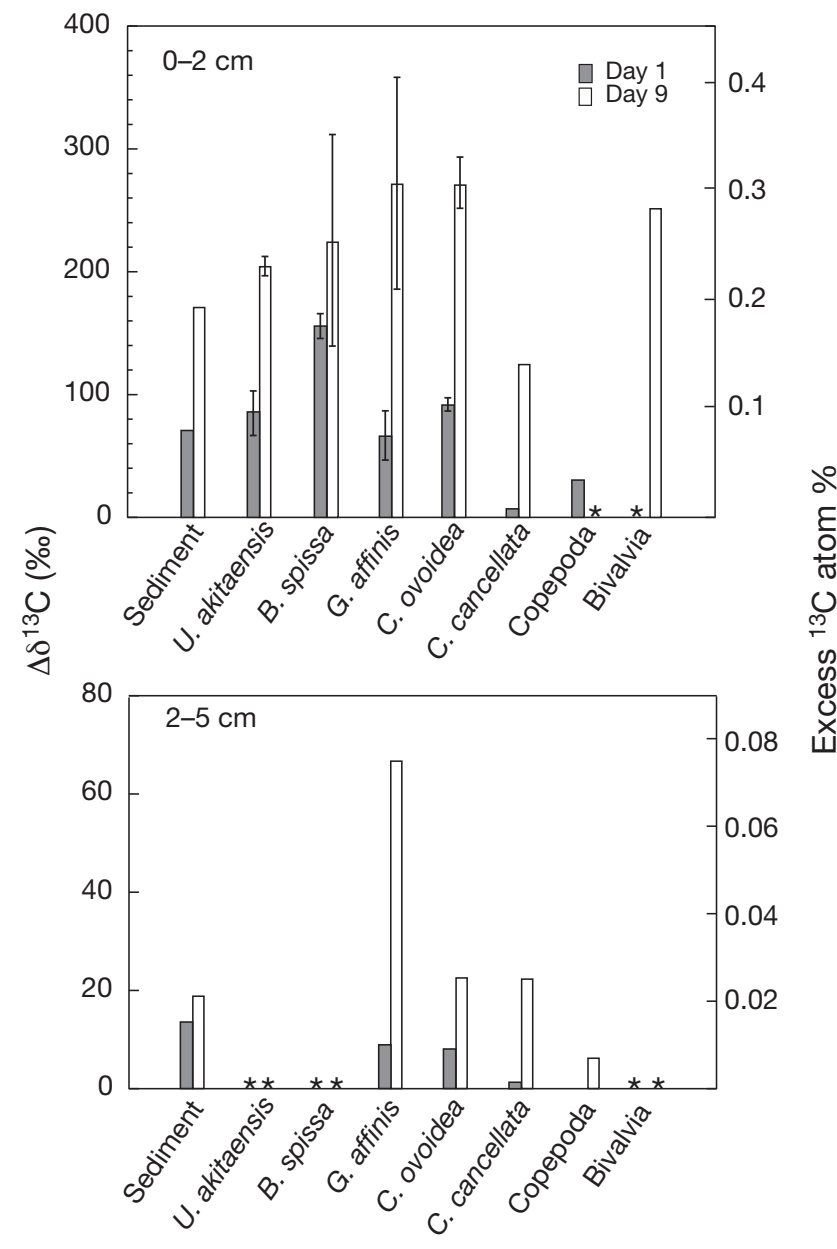

Fig. 3. Enrichment in ${ }^{13} \mathrm{C}$ of sedimentary total organic carbon, benthic foraminifera, and other meio- and macrofauna from cores to which glucose was added. Top: samples from sediments at a depth of 0 to $2 \mathrm{~cm}$; bottom: samples from sediments at a depth of 2 to $5 \mathrm{~cm}$. Error bars: SD (only for cores with replicate samples); *: no data. See Table S2 in the supplement at www.int-res.com/articles/suppl/m431p011_supp. pdf for raw data markedly as a function of time. In both the C-2 and C9 cores, ${ }^{13} \mathrm{C}$-labeled organic carbon was mixed to a depth of $5 \mathrm{~cm}$ in the sediments. Significant enrichment was not detected from the sediment layers deeper than $7 \mathrm{~cm}$ in the Chlorella sp. cores. In the G-0 core, ${ }^{13} \mathrm{C}$ labeled organic carbon had already reached a depth of $5 \mathrm{~cm}$ in the sediments. Although layers deeper than $5 \mathrm{~cm}$ were not examined for the G-1 core, the penetration depth of ${ }^{13} \mathrm{C}$-labeled organic carbon was $4 \mathrm{~cm}$, which was not deeper than that in the G-0 core. ${ }^{13} \mathrm{C}$ labeled organic carbon penetrated to the deepest part of the sediment layer (10 to $15 \mathrm{~cm}$ ) in the G-9 core, but the contribution to TOC was minor $(-19.0$ to $-13.3 \%$ o below the $5 \mathrm{~cm}$ depth in the sediment).

\section{Incorporation of ${ }^{13} \mathrm{C}$-labeled glucose by organisms}

Foraminifera exhibited modest glucose incorporation, with similar assimilation values among species (Fig. 3, Table S2 in the supplement). On Day 1, we detected ${ }^{13} \mathrm{C}$ originating from glucose in all 5 foraminiferal species in both the shallower and deeper layers. In the shallow layer, the labeling was highest in Bolivina spissa with $+155.8 \pm 10.1 \%$ (mean \pm SD of replicate samples) relative to Chilostomella ovoidea, Uvigerina akitaensis, and Globobulimina affinis, which exhibited $\Delta \delta^{13} \mathrm{C}$ of +66.7 to $92.1 \%$ o. ${ }^{13} \mathrm{C}$-labeling of those 4 species was similar to or greater than that in the shallow bulk sediments $(+70.9 \%$ o). In the deep layer, however, labeling in foraminifera was low for both $G$. affinis $(+9.1 \%$ ) and C. ovoidea $(+8.3 \%$ ), which was lower than that in the sediment $(+13.5 \%)$. Cyclammina cancellata showed minor enrichment in ${ }^{13} \mathrm{C}$ in both layers.

On Day 9, 2 deep-infaunal species, Globobulimina affinis $(+272.1 \pm 86.2 \%$ ) and Chilostomella ovoidea $\left(+272.5 \pm 20.8 \%\right.$ o), exhibited $\Delta \delta^{13} \mathrm{C}$ values higher than

Table 1. Concentrations and carbon isotopic compositions of archaeal core lipid biomarkers in the experimental cores. The concentrations are indicated as average $( \pm \mathrm{SD}, \mathrm{n}=3)$ values. The diether archaeol was not detected in any sample. See 'Materials and methods: Archaeal lipid quantification' and Fig. S1 in the supplement at www.int-res.com/articles/suppl/m431p011_supp.pdf for further explanation of archaeal membrane lipid biomarkers. GDGT: glycerol dialkyl glycerol tetraether

\begin{tabular}{|c|c|c|c|c|c|c|c|c|c|c|}
\hline \multirow[t]{2}{*}{ Core } & \multirow[t]{2}{*}{ Depth } & & & & \multicolumn{6}{|c|}{ Tetraether ( $\mu g^{-1}$ dry wt) } \\
\hline & & $\begin{array}{l}\text { Cald- } \\
\text { archaeol }\end{array}$ & $\begin{array}{c}\delta^{13} \mathrm{C}_{\text {caldarchaeol }} \\
(\% \text { o })\end{array}$ & GDGT1 & GDGT2 & GDGT3 & $\begin{array}{l}\text { Cren- } \\
\text { archaeol }\end{array}$ & $\begin{array}{c}\delta^{13} \mathrm{C}_{\text {crenarchaeol }} \\
(\%)\end{array}$ & $\begin{array}{l}\text { Regio- } \\
\text { isomer }\end{array}$ & Total \\
\hline \multirow[t]{2}{*}{ G-0 } & $0-1 \mathrm{~cm}$ & $5.1 \pm 1.2$ & \multirow[t]{2}{*}{-21.4} & $1.1 \pm 0.3$ & $1.0 \pm 0.1$ & $0.2 \pm 0.1$ & $5.1 \pm 5.6$ & \multirow[t]{2}{*}{-21.7} & $0.7 \pm 0.1$ & $13.3 \pm 4.0$ \\
\hline & $2-3 \mathrm{~cm}$ & $3.5 \pm 0.8$ & & $0.8 \pm 0.2$ & $0.7 \pm 0.1$ & $0.2 \pm 0.0$ & $7.5 \pm 1.8$ & & $0.6 \pm 0.1$ & $13.3 \pm 2.9$ \\
\hline \multirow[t]{2}{*}{ G-9 } & $0-1 \mathrm{~cm}$ & $4.1 \pm 0.8$ & \multirow[t]{2}{*}{45.7} & $0.9 \pm 0.0$ & $0.7 \pm 0.4$ & $0.2 \pm 0.0$ & $8.1 \pm 0.7$ & \multirow[t]{2}{*}{21.9} & $0.4 \pm 0.1$ & $14.5 \pm 2.1$ \\
\hline & $2-3 \mathrm{~cm}$ & $3.0 \pm 1.7$ & & $0.6 \pm 0.5$ & $0.7 \pm 0.3$ & $0.1 \pm 0.0$ & $6.0 \pm 3.8$ & & $0.4 \pm 0.1$ & $10.7 \pm 6.4$ \\
\hline \multirow[t]{2}{*}{ C-9 } & $0-1 \mathrm{~cm}$ & $3.8 \pm 0.2$ & \multirow[t]{2}{*}{192.4} & $1.0 \pm 0.1$ & $0.8 \pm 0.1$ & $0.2 \pm 0.0$ & $7.5 \pm 0.1$ & \multirow[t]{2}{*}{39.7} & $0.7 \pm 0.4$ & $14.0 \pm 0.1$ \\
\hline & $2-3 \mathrm{~cm}$ & $3.4 \pm 0.6$ & & $0.7 \pm 0.1$ & $0.8 \pm 0.2$ & $0.1 \pm 0.1$ & $7.5 \pm 1.0$ & & $0.7 \pm 0.3$ & $13.2 \pm 1.7$ \\
\hline
\end{tabular}


the shallow-infaunal species even in the shallow layer. Bolivina spissa, which exhibited the highest $\Delta \delta^{13} \mathrm{C}$ values on Day 1, exhibited $\Delta \delta^{13} \mathrm{C}$ values (+225.6 $\pm 86.1 \%$ ) lower than the above 2 deep-infaunal species and similar to that of Uvigerina akitaensis (+204.6 $\pm 7.8 \%$ ). Cyclammina cancellata was the only species that exhibited $\Delta \delta^{13} \mathrm{C}$ values lower than those of the sediment. However, the labeling of C. cancellata was much greater on Day 9 than on Day 1.

On Day 9, a Bivalvia specimen from the surface layer showed enrichment in ${ }^{13} \mathrm{C}$ at a concentration similar to those of benthic foraminifera. Copepod specimens from the shallow layer in the G-1 core and from the deep layer in the G-9 core showed slight ${ }^{13} \mathrm{C}$ enrichment in their bodies.

After $9 \mathrm{~d}$ of in situ incubation, archaeal membrane lipid biomarkers exhibited heavy carbon isotopic compositions, reaching 21.9 and $45.7 \%$ orenarchaeol and caldarchaeol, respectively (Table 1). ${ }^{13} \mathrm{C}$ enrichment was from +43.6 (crenarchaeol) to $+67.1 \%$ (caldarchaeol) relative to G-0 samples.

\section{Ingestion of ${ }^{13} \mathrm{C}$-labeled Chlorella sp.}

Chlorella sp. was ingested by some foraminiferal species within $9 \mathrm{~d}$, but the extent of incorporation differed markedly among species. On Day 2, only Uvigerina akitaensis and Cyclammina cancellata showed apparent incorporation of ${ }^{13} \mathrm{C}$-labeled Chlorella sp. in both shallow and deep sediment layers (Fig. 4, Table S3 in the supplement). Ingestion by other foraminiferal species, including bathysiphon and mudball (presumably Komokiacea), were negligible on Day 2. By Day 9, Bolivina spissa and Globobulimina affinis had ingested ${ }^{13}$ C-labeled Chlorella sp. in addition to U. akitaensis and C. cancellata. The ingestion was apparent in $U$. akitaensis at both depth layers as up to $41 \%$ (0 to $2 \mathrm{~cm}$ ) and $16 \%\left(2\right.$ to $5 \mathrm{~cm}$ ) of their $\mathrm{C}_{\text {org }}$ originated from ${ }^{13} \mathrm{C}$ labeled Chlorella sp. U. akitaensis from depths of 0 to $2 \mathrm{~cm}$ in the C-9 core showed contrasting ${ }^{13} \mathrm{C}$-enrichment depending on cytoplasm color (green or brown). The green $U$. akitaensis samples, in which the colour presumably reflects intracellular ${ }^{13} \mathrm{C}$-labeled Chlorella (Hemleben \& Kitazato 1995), exhibited $41 \pm 1.0 \%$ excess ${ }^{13} \mathrm{C}$ atom\%, while brown $U$. akitaensis exhibited $4.6 \pm 0.08 \%$ excess ${ }^{13} \mathrm{C}$. The other species had lower ${ }^{13} \mathrm{C}$-labeled Chlorella sp. concentrations in their biomass $(<2.5 \%)$. Large variations in the excess ${ }^{13} \mathrm{C}$ atom\% were observed between replicates of C. cancellata, which were measured in 1 to 3 specimens for each sample. While the labeling by $U$. akitaensis, $B$. spissa, and G. affinis increased from Day 2 to 9, that by $C$. cancellata decreased in the deeper layer. Chilostomella ovoidea showed modest ingestion of ${ }^{13} \mathrm{C}$ - labeled Chlorella sp. (0.027\% excess ${ }^{13} \mathrm{C}$ atom\%, i.e. $+23.6 \%$ of $\Delta \delta^{13} \mathrm{C}$ ).

Copepod samples at 2 to $5 \mathrm{~cm}$ sediment depth exhibited substantially high ${ }^{13} \mathrm{C}$ atom\% values both on Day 2 and 9 (Fig. 4, Table S3 in the supplement). On the other hand, polychaetes and cumaceans were not enriched in ${ }^{13} \mathrm{C}$ on Day 9.

Archaeal membrane lipid biomarkers were enriched in ${ }^{13} \mathrm{C}$ by +61.4 (crenarchaeol) to $+213.8 \%$ o (caldarchaeol) on Day 9 relative to G-0 samples (Table 1).

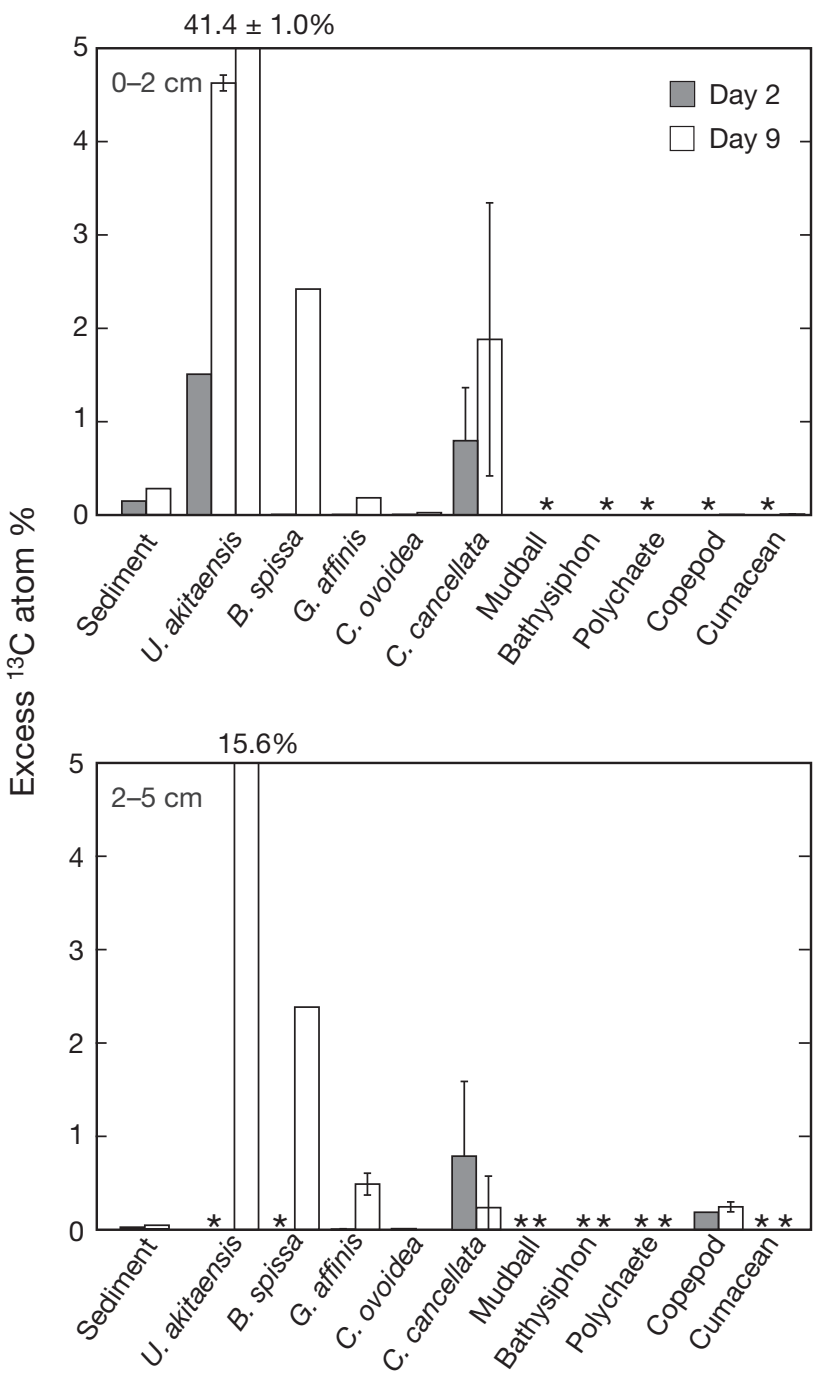

Fig. 4. Enrichment in ${ }^{13} \mathrm{C}$ of sedimentary total organic carbon, benthic foraminifera, and other meio- and macrofauna from cores to which Chlorella sp. was added. Top: samples from sediments at a depth of 0 to $2 \mathrm{~cm}$; bottom: samples from sediments at a depth of 2 to $5 \mathrm{~cm}$. Error bars: SD (only for cores with replicate samples); *: no data. Two different Day 9 columns for Uvigerina akitaensis in the top panel indicate values for specimens with brown cytoplasm (left column) and green cytoplasm (right column). Values above graphs show the extent of bars with excess ${ }^{13} \mathrm{C}$ atom $\%>5$. See Table $\mathrm{S} 3$ in the supplement at www. int-res.com/articles/suppl/m431p011_supp.pdf for raw data 


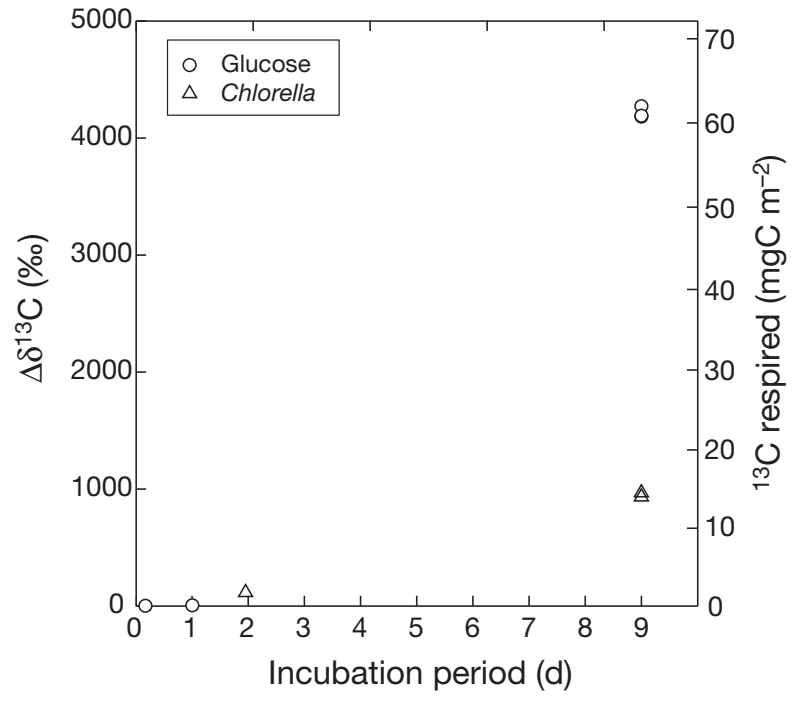

Fig. 5. $\Delta \delta^{13} \mathrm{C}(\%)$ of dissolved inorganic carbon extracted from the overlying water collected from the incubation cores. Right axis indicates the amount of respired carbon calculated based on the excess ${ }^{13} \mathrm{C}$ atom $\%$. Note that the 2 axes do not correlate linearly with each other. See Table S4 in the supplement at www.int-res.com/articles/suppl/m431p011_supp.pdf for raw data

\section{Mineralization of ${ }^{13} \mathrm{C}$-labeled glucose and Chlorella sp.}

The mineralization rates of the $2{ }^{13} \mathrm{C}$-labeled substrates increased during 0 to $9 \mathrm{~d}$ of in situ incubation, as reported for the mineralization of ${ }^{13} \mathrm{C}$-labeled algae addition in onboard experiments (Moodley et al. 2005, Andersson et al. 2008). Benthic mineralization of ${ }^{13} \mathrm{C}$ labeled substrates was modest within $2 \mathrm{~d}$ of incubation in both Chlorella sp. and glucose cores (Fig. 5). However, on Day 9, mineralization of label increased drastically with $\delta^{13} \mathrm{C}$-DIC values of $958.6 \pm 9.5 \%$ (SD of replicate sample bottles) and $4214.6 \pm 41.9 \%$ in the C9 and G-9 cores, respectively (Table S4 in the supplement). As a result, the amounts of respired ${ }^{13} \mathrm{C}$ added to the seafloor were 0.11 and $1.9 \mathrm{mg} \mathrm{C} \mathrm{m}^{-2}$ in the G-1 and $\mathrm{C}-2$ cores, respectively, and drastically increased to $14.4 \pm 0.14$ in the $\mathrm{C}-9$ and $61.3 \pm 0.58 \mathrm{mg} \mathrm{C} \mathrm{m}^{-2}$ in the G-9 core (Fig. 5).

\section{DISCUSSION}

\section{Glucose as an example of DOM in pore water}

In the present study, glucose was used as an example of DOM in pore water. Since glucose has a low molecular weight and is easily metabolized by heterotrophs, it may be representative of labile DOC sources in sediments. However, it is known that DOC in the ocean is largely dominated by refractory or semi-labile organic compounds. Labile DOM concentrations represent a small fraction ( 0 to $6 \%$ ) of bulk DOM in the open oceans (Carlson 2002). It is thus possible that the glucose used in the present study was not a typical DOC source for benthic fauna.

However, rapid turnover rates of glucose in experimental settings suggest that the fluxes of such labile DOM can be high (Fuhrman \& Ferguson 1986, Rich et al. 1996, Keil \& Kirchman 1999). Many sources of labile DOM such as bacterial ectoenzyme activities, bacterial cell lysis by viral attacks, and sloppy feeding by grazers support the high flux of labile DOM in the ocean. Because of the rapid cycling of labile DOM, these compounds are present in low concentrations and compose a small fraction of DOM, although the flux rate may potentially be high. Benthic fauna may also utilize such labile DOM. In the sedimentary pore water, the concentration of DOM is generally one order of magnitude higher than that in the overlying water, suggesting high production rates of DOM in sediments.

It was reported that the utilization of glucose differs substantially among different organisms. Glucose uptake contributed from 27 to $35 \%$ of net bacterial production in the equatorial Pacific (Rich et al. 1996) and up to $100 \%$ in the Arctic (Rich et al. 1997). On the other hand, glucose uptake only contributes $<11 \%$ of the bacterial production in the Gulf of Mexico and the Antarctic (Skoog et al. 1999, Kirchman et al. 2001). Many bacteria show higher growth rates with amino acids than with glucose and ammonium (Kirchman 1990). In some cases, acetate was a more preferable carbon source for bacteria relative to glucose and amino acids (Guilini et al. 2010). Marine invertebrates prefer fatty acids or algal-derived amino acids to glucose (Baines et al. 2005, de Goeij et al. 2008). It is probable that the incorporation of DOM differs substantially among organisms depending on the types of DOM available. The results of the present study should therefore be considered as specific examples of labile DOC uptake by the benthic community in Sagami Bay.

\section{Incorporation of algae and DOM by foraminifera}

The enrichment patterns of benthic foraminifera varied between the $2{ }^{13} \mathrm{C}$-labeled food materials. In the case of ${ }^{13} \mathrm{C}$-labeled Chlorella sp., Uvigerina akitaensis ingested food equivalent to up to $40 \%$ of their biomass within $9 \mathrm{~d}$, while Chilostomella ovoidea showed almost negligible ingestion of Chlorella sp. (Fig. 4). On the other hand, all the examined species incorporated similar amounts of glucose (Fig. 3). 
We used a single Chlorella species as a representative of algal materials although natural phytodetritus contains various materials (Beaulieu \& Smith 1998). Furthermore, Chlorella sp. has rather refractory cell walls mainly consisting of carbohydrates (Loos \& Meindl 1982). However, foraminiferal ingestion patterns of Chlorella sp. (Chlorophyta) during long-term incubation were generally similar to those of Dunaliella sp. (Chlorophyta) and Chaetoceros sp. (diatom) (Fig. 6), suggesting that the observed feeding behaviors of Chlorella sp. in the present study were general reactions to algal materials from the water column. Two shallow-infaunal species, Uvigerina akitaensis and Bolivina spissa, ingested substantial amounts of algae, although the former did so more quickly than the latter (Nomaki et al. 2005, present study). The deep-infaunal species Chilostomella ovoidea did not ingest substantial amounts of algae, while another deep-infaunal species, Globobulimina affinis, ingested algae slowly, but in measurable amounts. Differences in the foraminiferal response to algal materials in the current study compared with the responses reported in previous studies were: (1) apparent algal ingestion by Cyclammina cancellata, which showed negligible ingestion of algae in previous in situ feeding studies (Nomaki et al. 2005, 2006) and (2) modest ingestion of Chlorella sp. by B. spissa and G. affinis in the short term (Fig. 6). Previous studies were conducted in April, October, and November, while the present study was conducted in March. The environment on the seafloor in March is similar to that in April, since both are during the spring bloom season (Kitazato et al. 2003), and therefore seasonal changes in feeding behavior may be an unlikely contributing factor to the differences. ${ }^{13} \mathrm{C}$-labeled algal materials were added to sediments in similar manners in the present (Fig. 2) and previous studies (Nomaki et al. 2005), indicating that access to the food materials did not cause different reactions. Differences in algal species or in algal cell size could cause the different reactions by C. cancellata, B. spissa, and G. affinis. There was no replicate core for each time series, and therefore the different reactions could also be caused by heterogeneous distribution of foraminifera or reactions of individuals. Highly variable ingestion between individuals could also explain the apparent ingestion of Chlorella sp. by C. cancellata in the present study. It should be noted that the isotopic compositions of $C$. cancellata were typically measured with 1 specimen from each sample in our study (Tables S2 \& S3 in the supplement), while previous studies measured it in up to 10 specimens (Nomaki et al. 2005). Data on C. cancellata in the present study therefore reflect strong individual variations, whereas data on other species reflect the average incorporation by the species.
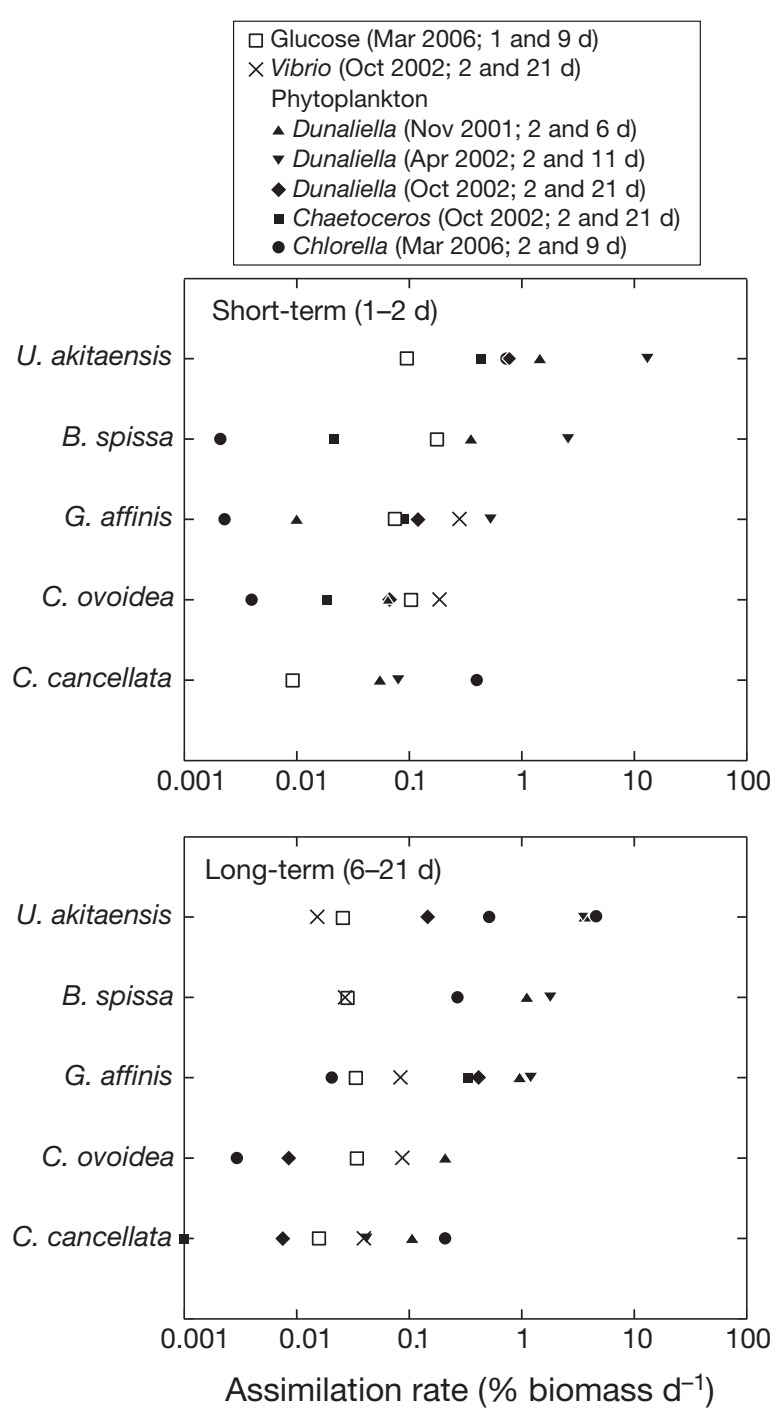

Fig. 6. Incorporation rates of ${ }^{13} \mathrm{C}$-labeled organic matter by 5 foraminiferal species measured during in situ feeding experiments (Nomaki et al. 2005, 2006, present study). Data from the uppermost $2 \mathrm{~cm}$ of sediment were weight-averaged and then normalized by dividing by the number of incubation days. The upper and lower graphs are based on short-term (1 or $2 \mathrm{~d}$ ) and long-term (6 to $21 \mathrm{~d}$ ) incubation data, respectively

Temporal labeling patterns differed between the glucose and Chlorella sp. experiments. Glucose was incorporated quickly by all species, while Chlorella sp. was incorporated after a relatively long time by certain species. The incorporation of Chlorella sp. increased dramatically with incubation time, while that of glucose increased slightly with time (Figs. $3 \& 4$ ). The excess ${ }^{13} \mathrm{C}$ in Uvigerina akitaensis, Globobulimina affinis, and Bolivina spissa in the C-9 core was 15-fold, 41fold, and 580-fold higher, respectively, than in the C-2 core, whereas these species exhibited a 2.4-fold, 4.1fold, and 1.4-fold higher excess of ${ }^{13} \mathrm{C}$ in the G-9 rela- 


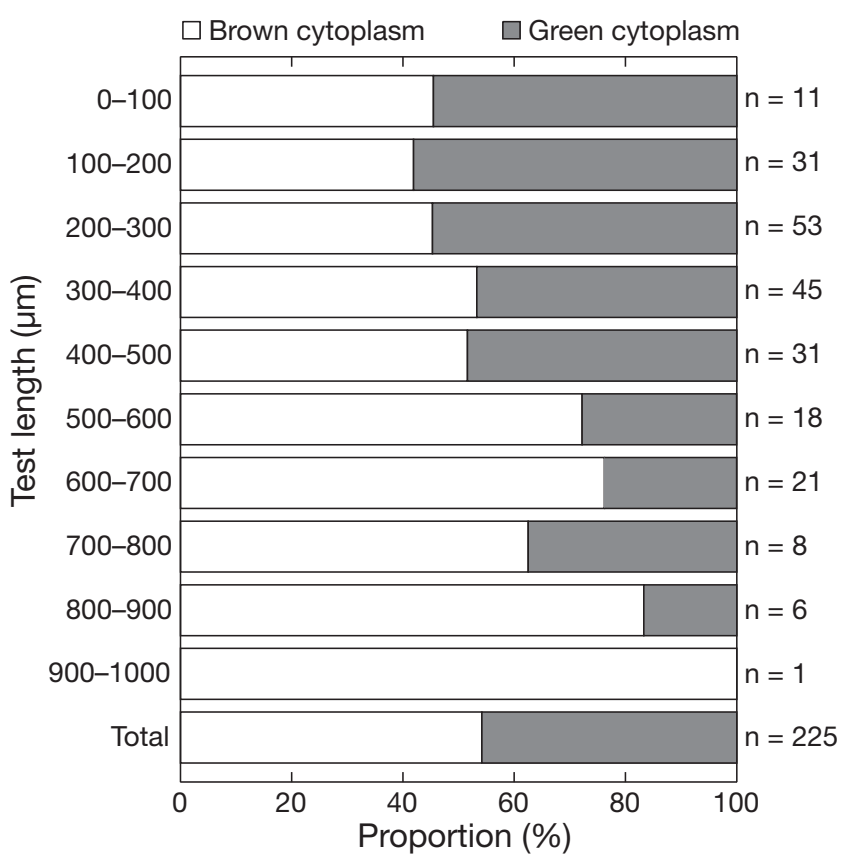

Fig. 7. Uvigerina akitaensis. Ratios of specimens with green or brown cytoplasm among different test lengths of $U$. akitaensis. Numbers of individuals in each size range are indicated on the right

tive to the G-1 core. The rapid incorporation of ${ }^{13} \mathrm{C}$ labeled glucose may reflect absorption through the cell surface (DeLaca et al. 1981). Algal materials were gathered by pseudopodial activity and then incorporated into food vacuoles, resulting in delayed incorporation relative to direct absorption of DOM. Incorporated glucose likely also was respired more quickly than Chlorella sp. (Fig. 5), resulting in the lack of assimilation on a longer time scale as seen in the Chlorella sp. cores. Phytodetritus may serve as episodic nourishment for some species, while DOC or bacterial carbon serves as a more constant energy source for many species (Fig. 6).

\section{Size-dependent ingestion of Chlorella sp. by Uvigerina akitaensis}

Uvigerina akitaensis from 0 to $2 \mathrm{~cm}$ sediment depth in the C-9 core showed contrasting ${ }^{13} \mathrm{C}$-enrichment depending on cytoplasm color (green or brown). While brown cytoplasm is the typical cytoplasm color for $U$. akitaensis, the green cytoplasm color reflects substantial amounts of Chlorella-chloroplast in foraminiferal cells. The green $U$. akitaensis samples exhibited a $41 \pm$ $1.0 \%$ excess ${ }^{13} \mathrm{C}$ atom $\%$, while brown $U$. akitaensis exhibited a $4.6 \pm 0.08 \%$ excess ${ }^{13} \mathrm{C}$ atom $\%$. Although $4.6 \%$ represents substantial incorporation of Chlorella sp., it is nearly 10-fold lower than that of green specimens collected from the same layer and after the same incubation period. The proportion of green specimens to total specimens was almost equal between the depths of 0 to $2 \mathrm{~cm}$ (green: 103 individuals, brown: 122 individuals $=45.8 \%)$ and 2 to $5 \mathrm{~cm}(9: 13=41 \%)$ in the sediments, where the concentrations of ${ }^{13} \mathrm{C}$-labeled Chlorella sp. differed (75.0 and $24.1 \mathrm{mg} \mathrm{C} \mathrm{m}^{-2}$ of ${ }^{13} \mathrm{C}$ labeled Chlorella sp. or its degraded material in the 0 to 2 and 2 to $5 \mathrm{~cm}$ layers, respectively; Fig. 2). This indicates that the modest incorporation of ${ }^{13} \mathrm{C}$-labeled Chlorella sp. by brown specimens was not caused by a lack of access to food material and further suggests that the ingestion of algae differ between individuals even in the same species.

Green specimens comprised 50 to $60 \%$ of all specimens $<400 \mu \mathrm{m}$, but 20 to $40 \%$ of those $>600 \mu \mathrm{m}$ (Fig. 7). Lee et al. (1966) observed that smaller ( 150 to $200 \mu \mathrm{m})$ specimens of Allogromia laticollaris ingested more food than larger (350 to $400 \mu \mathrm{m}$ ) ones. Similar size-dependent ingestion of bacteria was observed for the same species, although the numbers of samples were limited (Langezaal et al. 2005). This suggests that larger specimens tend to have a slower turnover rate than smaller ones. Highly variable incorporation between individuals was also observed in Cyclammina cancellata in all of our Chlorella sp. samples, in which 1 to 3 specimens were examined for each sample (Table S3 in the supplement). Differing responses to algal materials among the same macrofaunal species were also reported at an abyssal Pacific site (Sweetman \& Witte 2008). Size-dependent feeding preferences and/or $\mathrm{C}_{\text {org }}$ turnover may also be an important factor for understanding carbon cycling on the seafloor and the chemistry of the foraminifera.

\section{Enrichment in ${ }^{13} \mathrm{C}$ via microbial processes}

The in situ experiments were carried out for $9 \mathrm{~d}$. The $9 \mathrm{~d}$ interval may be sufficient to induce indirect ${ }^{13} \mathrm{C}$ enrichment of foraminifera or metazoans, i.e. the ingestion of ${ }^{13} \mathrm{C}$-labeled microbes that had incorporated ${ }^{13} \mathrm{C}$-glucose to build up their biomass. Guilini et al. (2010) reported that ${ }^{13} \mathrm{C}$-labeled glucose incorporation into bacterial membrane lipids in the sediments collected from $1280 \mathrm{~m}$ water depth took place $1 \mathrm{~d}$ after glucose injection and reached a maximum after 2 to $4 \mathrm{~d}$. The data on ${ }^{13} \mathrm{C}$-enrichment should therefore be considered specifically within this time period.

The enrichment in ${ }^{13} \mathrm{C}\left(\Delta \delta^{13} \mathrm{C}\right)$ of archaeal membrane lipid biomarkers were +43.6 and $+67.1 \%$ in the G-9 core (Table 1), implying that some of the enrichment in foraminiferal carbon could be caused by ingestion of microbes that had incorporated ${ }^{13} \mathrm{C}$-labeled glucose. 
Some benthic foraminiferal species are known to utilize bacterial carbon under experimental conditions (Lee et al. 1966, Bernhard \& Bowser 1992, Langezaal et al. 2005). However, the contributions of bacterial carbon to the total carbon requirements of foraminifera are generally low based on direct evaluation in labeling experiments (Nomaki et al. 2006, van Oevelen et al. 2006b, Pascal et al. 2008). Those results suggest that most of the ${ }^{13} \mathrm{C}$ enrichment in the present study did not depend on microbial processes. Moreover, foraminiferal enrichment in ${ }^{13} \mathrm{C}$ in the glucose cores was apparent on Day 1, but did not increase markedly thereafter, suggesting that the enrichment was not through indirect incorporation via microbial processes.

\section{Different fates of Chlorella sp. and glucose carbon on the deep seafloor}

A similar penetration pattern of Chlorella sp. and glucose down to $5 \mathrm{~cm}$ (Fig. 2) suggests that bioturbation largely exceeded pore water advection and the diffusion process at this depth, allowing comparable delivery of each ${ }^{13} \mathrm{C}$-labeled material. Below $5 \mathrm{~cm},{ }^{13} \mathrm{C}$ labeled Chlorella sp. or its degraded matter was not found, while ${ }^{13} \mathrm{C}$-labeled glucose or its subsequent products were found down to $15 \mathrm{~cm}$. This suggests that DOC can reach far deeper than particulate organic carbon, due to pore water advection or diffusion.

The recovered amounts of ${ }^{13} \mathrm{C}$-label found as respired carbon, in sedimentary TOC, in foraminiferal biomass, and in metazoan biomass during the experimental periods are summarized in Fig. 8. Since there was no replicate core for each time period, the exact values presented here include some uncertainty.

Mixed ${ }^{13} \mathrm{C}$ was mostly found as sedimentary organic carbon, including benthic biomass, in both Chlorella sp. and glucose cores (Fig. 8). After $9 \mathrm{~d}$, foraminiferal biomass was also an important sink for Chlorella sp. carbon on the seafloor. Benthic foraminifera stored $1.7 \%$ of initially added Chlorella sp. carbon, which represents $6.4 \%$ of the recovered label in the sediments at the end of the experiments. Little glucose carbon was found in foraminifera or metazoan biomass during the experimental period.

There were time lags of a few days between the settling of ${ }^{13} \mathrm{C}$-labeled substrates and their mineralization by the benthic community. Only 0.11 and $1.9 \mathrm{mg} \mathrm{m}^{-2}$ of added ${ }^{13} \mathrm{C}$ were respired in $\mathrm{G}-1$ and $\mathrm{C}-2$ cores, respectively (Fig. 5). Respired carbon then increased dramatically until Day 9. Roughly half of the recovered carbon was found as respired carbon in glucose cores, indicating rapid mineralization of glucose compared with Chlorella sp. carbon mineralization (Figs. 5 \& 8). The amounts of respired carbon estimated based on $\delta^{13} \mathrm{C}$

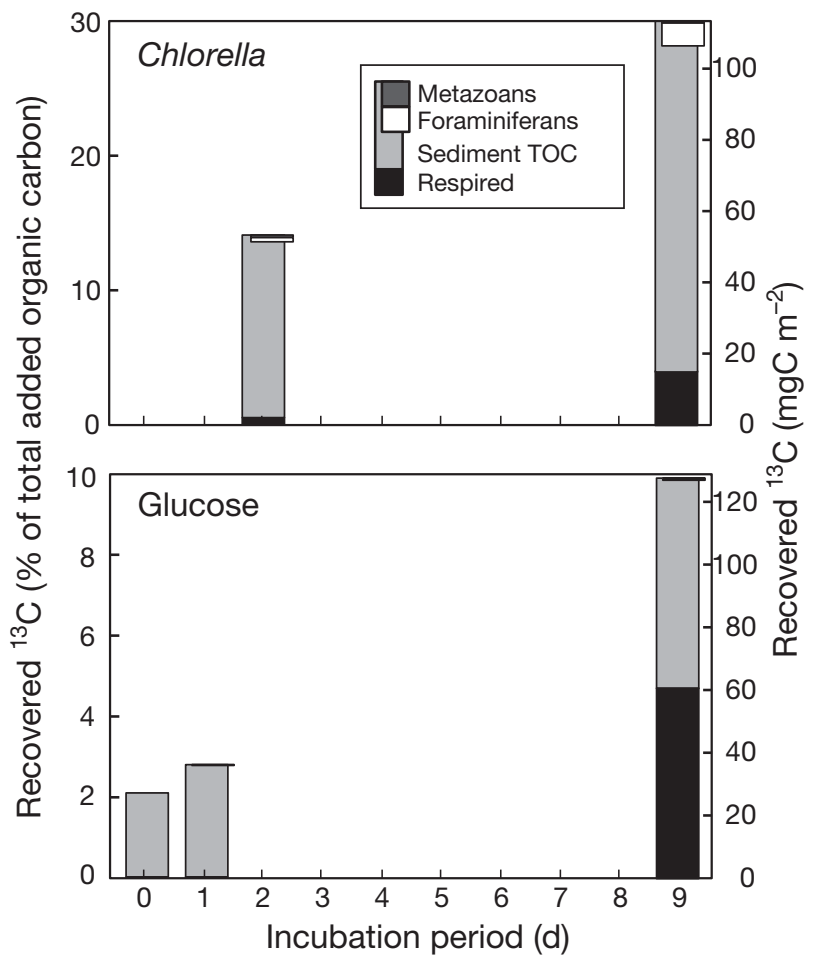

Fig. $8 .{ }^{13} \mathrm{C}$ proportion (of total organic carbon initially added to sediment cores) and mass recovered from dissolved inorganic carbon (respired), metazoans, benthic foraminifera, and sedimentary organic carbon (0 to $15 \mathrm{~cm}$ depth), including benthic biomass. Top: cores to which ${ }^{13} \mathrm{C}$-labeled Chlorella sp. was added. Bottom: cores to which ${ }^{13} \mathrm{C}$-labeled glucose was added. Some of the respired $\mathrm{CO}_{2}$ may have escaped from the core during incubation. Some metazoan taxa were not included in this calculation. See 'Discussion: Different fates of Chlorella sp. and glucose carbon on the deep seafloor' for further explanations

values of DIC in the overlying water may be somewhat underestimated because part of the respired carbon escaped from the core thorough the holes in the top (see 'Materials and methods: In situ feeding experiments').

After $9 \mathrm{~d}$ of in situ incubation, 26.4, 1.7, 0.1, and 3.8\% of added Chlorella sp. was detected in the bulk sediment, foraminiferal biomass, measured metazoan biomass, and respired $\mathrm{CO}_{2}$, respectively. The percentages of glucose were $5.3,0.04,0.00$, and $4.6 \%$, respectively. Nearly half of the recovered ${ }^{13} \mathrm{C}$ in the glucose cores was in the form of respired $\mathrm{CO}_{2}$, while that of Chlorella sp. was found mainly as sedimentary organic matter. Among the benthic fauna, metazoans measured in the present study (polychaetes, cumaceans, bivalves, and copepods) were not responsible for the processing of Chlorella sp. and glucose. As some taxa may have been lost during sample processing or isolation (see 'Materials and methods: Sample processing'), total contribution of metazoans may be larger to some extent. Nematodes, which exhibited the second largest 
biomass in metazoan meiofauna after copepods at this site (Shimanaga \& Shirayama 2000, Nomaki et al. 2005), were not measured in the current study. Although deep-sea nematodes often showed limited uptake of phytoplankton in tracer studies (Nomaki et al. 2005, Ingels et al. 2010, Gontikaki et al. 2011), they could contribute to the DOC processing somewhat (Shirayama 1992) and may have been responsible for some of the glucose processing in our experiments. Some macrobenthos and megabenthos, e.g. Ophiuroida and Spatangoida, also exsist at this site (Nomaki et al. 2008), but they were not sampled in this experiment due to their patchy distribution on the seafloor.

Benthic foraminifera play important roles in phytodetritus processing by assimilating substantial amounts of algal carbon. Their importance is based on both their large biomass (e.g. our study site; Nomaki et al. 2005) and their high capacity of algal ingestion per unit biomass (Moodley et al. 2002, Nomaki et al. 2005, Gooday et al. 2008). Labile DOM may also serve as an accessible food source for certain benthic organisms including foraminifera, but it is then quickly mineralized on the deep seafloor. Although microbial incorporation was not quantified in the present study, the potential abundance of microbes on the deep seafloor and enrichment in archaeal membrane lipids in ${ }^{13} \mathrm{C}$ in the C-9 and G-9 cores (Table 1) suggest a significant contribution by microbes to benthic carbon processes.

Acknowledgements. We are grateful to the crew of the RV 'Natsushima' and the operation team of the ROV 'Hyper-Dolphin'. We appreciate the helpful comments of the editor and 3 anonymous reviewers, which improved the manuscript significantly. This research was financially supported by a Sasakawa Scientific Research Grant from the Japan Science Society to H.N. and by a Grant-in-Aid for Scientific Research from the Ministry of Education, Culture, Sports, Science and Technology, Japan (Young Scientists B No. 20740302 to H.N. and Scientific Research B No. 14340156 and Scientific Research A 17204046 to H.K.) and a Grant-in-Aid for Creative Scientific Research (19GS0211).

\section{LITERATURE CITED}

> Aberle N, Witte U (2003) Deep-sea macrofauna exposed to a simulated sedimentation event in the abyssal NE Atlantic: in situ pulse-chase experiments using ${ }^{13} \mathrm{C}$-labelled phytodetritus. Mar Ecol Prog Ser 251:37-47

> Andersson JH, Woulds C, Schwartz M, Cowie GL, Levin LA, Soetaert K, Middelburg JJ (2008) Short-term fate of phytodetritus in sediments across the Arabian Sea Oxygen Minimum Zone. Biogeosciences 5:43-53

Baines SB, Fisher NS, Cole JJ (2005) Uptake of dissolved organic matter (DOM) and its importance to metabolic requirements of the zebra mussel, Dreissena polymorpha. Limnol Oceanogr 50:36-47

Beaulieu SE, Smith KL (1998) Phytodetritus entering the ben- thic boundary layer and aggregated on the sea floor in the abyssal NE Pacific: macro- and microscopic composition. Deep-Sea Res II 45:781-815

Bernhard JM, Bowser SS (1992) Bacterial biofilms as a trophic resource for certain benthic foraminifera. Mar Ecol Prog Ser 83:263-272

Boucher Y, Kamekura M, Doolittle W (2004) Origins and evolution of isoprenoid lipid biosynthesis in archaea. Mol Microbiol 52:515-527

Burdige DJ (2002) Sediment pore waters. In: Hansell DA, Carlson CA (eds) Biogeochemistry of marine dissolved organic matter. Academic Press, San Diego, CA, p 611-663

Cahet G, Daumas R, Sibuet M (1990) In situ experimentation at the water/sediment interface in the deep sea. 2. Biotransformation of dissolved organic substrates by microbial communities at $2000 \mathrm{~m}$ depth in the Bay of Biscay. Prog Oceanogr 24:169-178

Campos-Creasey LS, Tyler PA, Gage JD, John AWG (1994) Evidence for coupling the vertical flux of phytodetritus to the diet and seasonal life history of the deep-sea echinoid Echinus affinis. Deep-Sea Res I 41:369-388

Carlson CA (2002) Production and removal processes. In: Hansell DA, Carlson CA (eds) Biogeochemistry of marine dissolved organic matter. Academic Press, San Diego, CA, p 91-151

de Goeij JM, Moodley L, Houtekamer M, Carballeira NM, van Duyl FC (2008) Tracing ${ }^{13} \mathrm{C}$-enriched dissolved and particulate organic carbon in the bacteria containing coral reef sponge Halisarca caerulea: evidence for DOM feeding. Limnol Oceanogr 53:1376-1386

DeLaca TE (1982) The use of dissolved amino acids by the foraminifer Notodendrodes antarctikos. Am Zool 22: 683-690

DeLaca TE, Karl DM, Lipps JH (1981) Direct use of dissolved organic carbon by agglutinated benthic foraminifera. Nature 289:287-289

> DeLong EF, King LL, Massana R, Cittone H, Murray A, Schleper C, Wakeham SG (1998) Dibiphytanyl ether lipids in nonthermophilic crenarchaeotes. Appl Environ Microbiol 64:1133-1138

> Drazen JC, Smith KL, Baldwin RJ (1998) Sediment community response to a temporally varying food supply at an abyssal station in the NE Pacific. Deep-Sea Res II 45: 893-913

> Fuhrman JA, Ferguson RL (1986) Nanomolar concentrations and rapid turnover of dissolved free amino acids in seawater: agreement between chemical and microbiological measurements. Mar Ecol Prog Ser 33:237-242

Gontikaki E, Mayor DJ, Narayanaswamy BE, Witte U (2011) Feeding strategies of deep-sea sub-Arctic macrofauna of the Faroe-Shetland Channel: combining natural stable isotopes and enrichment techniques. Deep-Sea Res I 58: 160-172

> Gooday AJ (1988) A response by benthic foraminifera to the deposition of phytodetritus in the deep sea. Nature 332: $70-73$

> Gooday AJ, Turley CM (1990) Response by benthic organisms to inputs of organic material to the ocean floor: a review. Philos Trans R Soc Lond A 331:119-138

Gooday AJ, Nomaki H, Kitazato H (2008) Modern deep-sea benthic foraminifera: a brief review of their morphologybased biodiversity and trophic diversity. In: Biogeochemical controls on palaeoceanographic proxies. Geological Society of London Special Publications 303:97-119

Graf G (1987) Benthic energy flow during a simulated autumn bloom sedimentation. Mar Ecol Prog Ser 39:23-29

Gudmundsson G, von Schmalensee M, Svavarsson J (2000) 
Are foraminifers (Protozoa) important food for small isopods (Crustacea) in the deep sea? Deep-Sea Res I 47: 2093-2109

Guilini K, van Oevelen D, Soetaret K, Middelburg JJ, Vanreusel A (2010) Nutritional importance of benthic bacteria for deep-sea nematodes from the Arctic ice margin: results of an isotope tracer experiment. Limnol Oceanogr 55: 1977-1989

Hemleben C, Kitazato H (1995) Deep-sea foraminifera under long time observation in the laboratory. Deep-Sea Res I 42: 827-832

> Hickman CS, Lipps JH (1983) Foraminiferivory: selective ingestion of foraminifera and test alterations produced by the neogastropod Olivella. J Foraminifer Res 13:108-114

Huguet C, Hopmans EC, Febo-Ayala W, Thompson DH, Sinninghe Damsté JS, Schouten S (2006) An improved method to determine the absolute abundance of glycerol dibiphytanyl glycerol tetraether lipids. Org Geochem 37: 1036-1041

Ingels J, Van den Driessche P, De Mesel I, Vanhove S, Moens T, Vanreusel A (2010) Preferred use of bacteria over phytoplankton by deep-sea nematodes in polar regions. Mar Ecol Prog Ser 406:121-133

Kanda J, Fujiwara S, Kitazato H, Okada Y (2003) Seasonal and annual variation in the primary production regime in the central part of Sagami Bay. Prog Oceanogr 57:17-30

Keil RG, Kirchman DL (1999) Utilization of dissolved protein and amino acids in the northern Sargasso Sea. Aquat Microb Ecol 18:293-300

Kirchman DL (1990) Limitation of bacterial growth by dissolved organic matter in the subarctic Pacific. Mar Ecol Prog Ser 62:47-54

Kirchman DL, Meon B, Ducklow HW, Carlson CA, Hansell DA, Steward GF (2001) Glucose fluxes and concentrations of dissolved combined neutral sugars (polysaccharides) in the Ross Sea and Polar Front Zone, Antarctica. Deep-Sea Res II 48:4179-4197

Kitazato H, Shirayama Y, Nakatsuka T, Fujiwara S and others (2000) Seasonal phytodetritus deposition and responses of bathyal benthic foraminiferal populations in Sagami Bay, Japan: preliminary results from 'Project Sagami 1996-1999'. Mar Micropaleontol 40:135-149

Kitazato H, Nakatsuka T, Shimanaga M, Kanda J and others (2003) Long-term monitoring of the sedimentary process in the central part of Sagami Bay, Japan: rationale, logistics and overview of results. Prog Oceanogr 57:3-16

Koga Y, Morii H (2007) Biosynthesis of ether-type polar lipids in archaea and evolutionary considerations. Microbiol Mol Biol Rev 71:97-120

Koga Y, Nakano M (2008) A dendrogram of archaea based on lipid component parts composition and its relationship to rRNA phylogeny. Syst Appl Microbiol 31:169-182

Komada T, Anderson MR, Dorfmeier CL (2008) Carbonate removal from coastal sediments for the determination of organic carbon and its isotopic signatures, $\delta 13 \mathrm{C}$ and $\Delta 14 \mathrm{C}$ : comparison of fumigation and direct acidification by hydrochloric acid. Limnol Oceanogr Methods 6:254-262

Langezaal AM, Jannink NT, Pierson ES, Van der Zwaan GJ (2005) Foraminiferal selectivity towards bacteria: an experimental approach using a cell-permeant stain. J Sea Res 54:256-275

Lee JJ, McEnery M, Pierce S, Freudenthal HD, Muller WA (1966) Tracer experiments in feeding littoral foraminifera. J Protozool 13:659-670

Libes SM (2009) Introduction to marine biogeochemistry, 2nd edn. Academic Press, New York, NY

Lipp JS, Morono Y, Inagaki F, Hinrichs K (2008) Significant contribution of Archaea to extant biomass in marine subsurface sediments. Nature 454:991-994

Lochte K, Turley CM (1988) Bacteria and cyanobacteria associated with phytodetritus in the deep sea. Nature 333: $67-69$

Loos E, Meindl D (1982) Composition of the cell wall of Chlorella fusca. Planta 156:270-273

- Middelburg JJ, Barranguet C, Boschker HTS, Herman PMJ, Moens T, Heip CHR (2000) The fate of intertidal microphytobenthos carbon: an in situ ${ }^{13} \mathrm{C}$-labeling study. Limnol Oceanogr 45:1224-1234

Moodley L, Middelburg JJ, Boschker HTS, Duineveld GCA, Pel R, Herman PMJ, Heip CHR (2002) Bacteria and foraminifera: key players in a short-term deep-sea benthic response to phytodetritus. Mar Ecol Prog Ser 236:23-29

Moodley L, Middelburg JJ, Soetaert K, Boschker HTS, Herman PMJ, Heip CHR (2005) Similar rapid response to phytodetritus deposition in shallow and deep-sea sediments. J Mar Res 63:457-469

Nakatsuka T, Masuzawa T, Kanda J, Kitazato H, Shirayama Y, Shimanaga M, Yamaoka A (2003) Particle dynamics in the deep water column of Sagami Bay, Japan. I. Origins of apparent flux of sinking particles. Prog Oceanogr 57: 31-46

Nomaki H, Heinz P, Nakatsuka T, Shimanaga M, Kitazato H (2005) Species-specific ingestion of organic carbon by deep-sea benthic foraminifera and meiobenthos: in situ tracer experiments. Limnol Oceanogr 50:134-146

> Nomaki H, Heinz P, Nakatsuka T, Shimanaga M and others (2006) Different ingestion patterns of ${ }^{13} \mathrm{C}$-labeled bacteria and algae by deep-sea benthic foraminifera. Mar Ecol Prog Ser 310:95-108

Nomaki H, Ogawa NO, Ohkouchi N, Suga H and others (2008) Benthic foraminifera as trophic links between phytodetritus and benthic metazoans: carbon and nitrogen isotopic evidence. Mar Ecol Prog Ser 357:153-164

Nomaki H, Ohkouchi N, Heinz P, Suga H and others (2009) Degradation of algal lipids by benthic foraminifera: an in situ tracer experiment. Deep-Sea Res I 56:1488-1503

Ogawa NO, Nagata T, Kitazato H, Ohkouchi N (2010) Ultrasensitive elemental analyzer/isotope ratio mass spectrometer for stable nitrogen and carbon isotope analyses. In: Ohkouchi N, Tayasu I, Koba K (eds) Earth, life and isotopes. Kyoto University Press, Kyoto, p 339-353

> Pascal PY, Dupuy C, Richard P, Niquil N (2008) Bacterivory in the common foraminifer Ammonia tepida: isotope tracer experiment and the controlling factors. J Exp Mar Biol Ecol 359:55-61

Pfannkuche O (1993) Benthic response to the sedimentation of particulate organic matter at the BIOTRANS station, $47^{\circ} \mathrm{N}, 20^{\circ} \mathrm{W}$. Deep-Sea Res II 40:135-149

> Pfannkuche O, Boetius A, Lochte K, Lundgreen U, Thiel H (1999) Responses of deep-sea benthos to sedimentation patterns in the North-East Atlantic in 1992. Deep-Sea Res I 46:573-596

Rich JH, Ducklow HW, Kirchman DL (1996) Concentrations and uptake of neutral monosaccharides along $140^{\circ} \mathrm{W}$ in the equatorial Pacific: contribution of glucose to heterotrophic bacterial activity and the DOM flux. Limnol Oceanogr 41:595-604

> Rich J, Gosselin M, Sherr E, Sherr B, Kirchman DL (1997) High bacterial production, uptake and concentrations of dissolved organic matter in the Central Arctic Ocean. Deep-Sea Res II 44:1645-1663

Sawyer TE, King GM (1993) Glucose uptake and end product formation in an intertidal marine sediment. Appl Environ Microbiol 59:120-128 
Shimanaga M, Shirayama Y (2000) Response of benthic organisms to seasonal change of organic matter deposition in the bathyal Sagami Bay, central Japan. Oceanol Acta 23:91-107

Shimanaga M, Lee W, Nomaki H, Iijima K (2009) Sex ratio and gut contents of the deep-sea harpacticoid Neocervinia itoi and other cerviniids: a possibility of reduced foraging among males. J Crustac Biol 29:183-191

Shirayama Y (1992) Preliminary studies on the energy budget of a deep-sea nematode. Mer (Paris) 29:170-173

Sinninghe Damsté JS, Schouten S, Hopmans EC, van Duin ACT, Geenevasen JAJ (2002) Crenarchaeol: the characteristic core glycerol dibiphytanyl glycerol tetraether membrane lipid of cosmopolitan pelagic crenarchaeota. J Lipid Res 43:1641-1651

Skoog A, Biddanda B, Benner R (1999) Bacterial utilization of dissolved glucose in the upper water column or the Gulf of Mexico. Limnol Oceanogr 44:1625-1633

Sweetman AK, Witte U (2008) Response of an abyssal macrofaunal community to a phytodetrital pulse. Mar Ecol Prog Ser 355:73-84

Takano Y, Chikaraishi Y, Ogawa NO, Kitazato H, Ohkouchi N (2009) Compound-specific nitrogen isotope analysis of D-,

Editorial responsibility: Hans Heinrich Janssen, Oldendorf/Luhe, Germany
L-alanine and valine: application of diastereomer separation to $\delta^{15} \mathrm{~N}$ and microbial peptidoglycan studies. Anal Chem 81:394-399

- Takano Y, Chikaraishi Y, Ogawa NO, Nomaki H and others (2010) Sedimentary membrane lipids recycled by deepsea benthic archaea. Nat Geosci 3:858-861

Tyler PA, Gage JD (1984) Seasonal reproduction of Echinus affinis (Echinodermata: Echinoidea) in the Rockall Trough, Northeast Atlantic Ocean. Deep-Sea Res 31:387-402

van Oevelen D, Middelburg JJ, Soetaert K, Moodley L (2006a) The fate of bacterial carbon in an intertidal sediment: modeling an in situ isotope tracer experiment. Limnol Oceanogr 51:1302-1314

> van Oevelen D, Moodley L, Soetaert K, Middelburg JJ (2006b) The trophic significance of bacterial carbon in a marine intertidal sediment: results of an in situ stable isotope labeling study. Limnol Oceanogr 51:2349-2359

> Witte U (1996) Seasonal reproduction in deep-sea sponges triggered by vertical particle flux? Mar Biol 124:571-581

Woulds C, Cowie GL, Levin LA, Andersson JH and others (2007) Oxygen as a control on seafloor biological communities and their roles in sedimentary carbon cycling. Limnol Oceanogr 52:1698-1709

Submitted: August 31, 2010; Accepted: March 23, 2011

Proofs received from author(s): May 27, 2011 